\title{
The hidden financial hurdles of commitment to Ophthalmology in the current UK training system
}

\author{
Jonathan Nairn ${ }^{1} \cdot$ John Ferris ${ }^{2} \cdot$ David Lockington ${ }^{1}{ }^{1}$
}

Received: 5 July 2019 / Accepted: 25 July 2019 / Published online: 4 October 2019

(C) The Royal College of Ophthalmologists 2019

\section{To the Editor:}

Ophthalmology speciality training in the UK is highly desirable, yet competitive (2018 ratio 4:1) [1]. Approximately 400 candidates engage in a yearly national recruitment process, presenting a portfolio of achievement based on the advice from the Severn Deanery website. The real-world cost of this portfolio is unknown. We are aware of some Scottish
Deaneries that have no allocated study leave budget for Foundation Years (outside of resuscitation and medical simulation courses). As the BMA estimates an average UK medical student debt at graduation is $£ 70,000$ [2], we wished to quantify the potential costs of producing a competitive application. We also wished to highlight hidden OST costs.

We estimated costs from 2018/19 candidate information on the national recruitment website, and mandatory training

Table 1 Table detailing likely events to produce a competitive ophthalmology portfolio, the published registration costs and the hidden additional costs of travel (approximately $£ 100$ ) and subsistence and accommodation (approximately $£ 150$ per day)

\begin{tabular}{|c|c|c|}
\hline $\begin{array}{l}\text { Example of potential achievements detailed on Severn Deanery website for the } \\
\text { ophthalmology application portfolio }\end{array}$ & $\begin{array}{l}\text { Expected } \\
\text { event cost }\end{array}$ & Additional hidden costs \\
\hline Part 1 FRCOphth (written exam; various national centres, 1 day event) & $£ 555$ & $£ 250$ (1 return travel, 1 night $\mathrm{B} \& \mathrm{~B})$ \\
\hline Refraction certificate (practical exam; held in Birmingham or London, 1 day event) & $£ 660$ & $£ 250$ ( 1 return travel, 1 night $\mathrm{B} \& \mathrm{~B})$ \\
\hline Microsurgical skills course 2018 (held at RCOphth London, 3 days event) & $£ 685$ & $£ 700$ (1 return travel, 4 nights $\mathrm{B} \& \mathrm{~B})$ \\
\hline $\begin{array}{l}\text { Ophthalmology undergraduate elective arrangement costs (as charged by University of } \\
\text { Glasgow in 2018; 4-6 weeks duration) }\end{array}$ & $£ 150$ & - \\
\hline $\begin{array}{l}\text { Regional conference } \pm \text { presentation in } 2018 \text { eg., Scottish Ophthalmological Club } \\
\text { (rotating Scottish centres, } 1 \text { day) }\end{array}$ & $£ 130$ & $£ 50$ (1 return regional travel) \\
\hline $\begin{array}{l}\text { National meeting attendance } \pm \text { presentation in } 2018 \\
\text { eg., RCOphth Annual Congress (rotating UK Centres, } 4 \text { days) }\end{array}$ & $£ 173$ & $\begin{array}{l}£ 700 \\
(1 \text { return travel, } 4 \text { nights } \mathrm{B} \& \mathrm{~B})\end{array}$ \\
\hline $\begin{array}{l}\text { International meeting attendance } \pm \text { presentation in } 2018 \\
\text { eg., European Society of Cataract \& Refractive Surgeons annual meeting (rotating EU } \\
\text { centres, } 4 \text { days) }\end{array}$ & $£ 50$ & $£ 700$ (1 return travel, 4 nights $B \& B$ ) \\
\hline Professional printing of portfolio & $£ 25$ & - \\
\hline Potential subtotal costs & $£ 2428$ & $£ 2650$ \\
\hline Total costs & $£ 5078$ & \\
\hline
\end{tabular}

Supplementary information The online version of this article (https:// doi.org/10.1038/s41433-019-0619-4) contains supplementary material, which is available to authorised users.

David Lockington

davidlockington@hotmail.com

1 Tennent Institute of Ophthalmology, Gartnavel General Hospital, 1053 Great Western Road, Glasgow G12 0YN, UK
2 Gloucestershire Eye Unit, Cheltenham, UK 
Table 2 Table detailing mandatory events to achieve Ophthalmology training as documented by the Academy of Medical Royal Colleges 2017 report (AoMRC), the published registration costs, and the hidden additional costs of travel (approx. £100) and subsistence and accommodation (approx. $£ 150$ per day), accounting for a $42 \%$ underestimation of real-world costs

\begin{tabular}{|c|c|c|}
\hline AoMRC mandatory ophthalmology training events & $\begin{array}{l}\text { Expected cost as } \\
\text { per AoMRC report }\end{array}$ & Additional hidden costs \\
\hline Part 1 FRCOphth—(written exam: various national centres, 1 day) & $£ 555$ & $£ 100$ ( 1 return travel) \\
\hline Refraction certificate-(Birmingham or London, 1 day) & $£ 660$ & $\begin{array}{l}£ 250 \text { ( } 1 \text { return travel, } 1 \text { night } \mathrm{B} \& \mathrm{~B} \\
\text { accommodation) }\end{array}$ \\
\hline Microsurgical skills course (London, 3 days) & $£ 685$ & $\begin{array}{l}£ 700 \text { ( } 1 \text { return travel, } 4 \text { nights } \mathrm{B} \& \mathrm{~B} \\
\text { accommodation) }\end{array}$ \\
\hline Part 2 FRCOphth written-(national centres, 1 day) & $£ 405$ & $\begin{array}{l}£ 250 \text { ( } 1 \text { return travel, } 1 \text { night } \mathrm{B} \& \mathrm{~B} \\
\text { accommodation) }\end{array}$ \\
\hline $\begin{array}{l}\text { Part } 2 \text { FRCOpth (Oral exam, Cardiff, Wolverhampton or } \\
\text { Singapore } 1 \text { day) }\end{array}$ & $£ 635$ & $\begin{array}{l}£ 250 \text { ( } 1 \text { return travel, } 1 \text { night } \mathrm{B} \& \mathrm{~B} \\
\text { accommodation) }\end{array}$ \\
\hline Royal College of Ophthalmology annual membership fees ST1-ST7 & $£ 2148$ & - \\
\hline Subtotal costs & $£ 5088$ & $£ 2150$ \\
\hline Likely total costs & $£ 7238$ & \\
\hline
\end{tabular}

costs from RCOphth curriculum [3] (see Supplementary Figure).

Table 1 calculates the various expenses associated with suggested portfolio achievements, approximately $£ 2428$. Table 2 shows breakdown of mandatory OST training costs (£5088). Neither of these figures include real-world costs of travel (approximately £100), accommodation and subsistence (estimated $£ 150$ per night), which could double estimated figures.

Significant financial hurdles already exist in a climate of growing graduate debt, particularly affecting students from lower socio-economic backgrounds, and those with dependants [2]. Additional 'hidden costs' of training were highlighted as causing low morale by the recent 'Enhancing junior doctor's working lives' Report and this was the inspiration for this study [4]. We raise concerns that the AoMRC report has underestimated financial costs of OST by at least $40 \%$, and does not include Part 1 and 2 revision courses (like Oculus). Such inaccurate calculations undervaluing the true costs of training jeopardises realistic planning of local study budgets by regional deaneries, placing financial pressure on individuals and potentially limiting access to educational opportunities. These costs are further influenced by geographical location (travel/accommodation), which may ultimately lead to inequality of opportunities. Recent surgical publications suggest trainees achieve their educational requirements at substantial personal expenditure [5].

We wish to encourage a realistic approach to study budget levels, hoping that the publication of our estimates will start dialogue regarding training requirements and appropriate funding for junior doctors.

\section{Compliance with ethical standards}

Conflict of interest The authors declare that they have no conflict of interest.

Publisher's note Springer Nature remains neutral with regard to jurisdictional claims in published maps and institutional affiliations.

\section{References}

1. Health Education England. Speciality training. Competition ratios. London: Health Education England; 2018. https://specialtytraining. hee.nhs.uk/Portals/1/Content/Resource\%20Bank/Competition\%20Ra tio\%27s/Competition\%20Ratios\%202018.pdf. Accessed 3 Jun 2019.

2. Ercolani MG, Vohra RS, Carmichael F, Mangat K, Alderson D. The lifetime cost to English students of borrowing to invest in a medical degree: a gender comparison using data from the Office for National Statistics. BMJ Open. 2015;5:e007335. https://doi.org/10. 1136/bmjopen-2014-007335.

3. Academy of Medical Royal Colleges. Mandatory Training Costs Report. London: Academy of Medical Royal Colleges; 2017. http://www.aomrc.org.uk/wp-content/uploads/2017/10/Cost_of_tra ining_301017-rev1.pdf. Accessed 7 May 2019.

4. Health Education England. Enhancing Junior Doctors' Working Lives Report. London: Health Education England; 2018. https://www.hee.nhs.uk/sites/default/files/documents/EJDWL\%20\%202018\%20progress\%20report.pdf. Accessed 7 May 2019.

5. O'Callaghan J, Mohan HM, Sharrock A, Gokani V, Fitzgerald JE, Williams AP, et al. Council of the association of surgeons in training. Cross-sectional study of the financial cost of training to the surgical trainee in the UK and Ireland. BMJ Open. 2017;7:e018086. https:// doi.org/10.1136/bmjopen-2017-018086. 